\title{
Judge Consideration of Religious Court Of Blora on Application of Married Dispensation
}

\begin{abstract}
Siti Muzazanah ${ }^{1}$, Akhmad Khisni ${ }^{2}$ and Rozihan ${ }^{3}$
Abstract. This study aims to know the factors increasing request for married dispensation, the judge in the consideration granted married dispensation and know the weaknesses of Marriage Act in court and in the implementation of solutions to reduce married dispensation, The method used normative juridical, namely legal research based on secondary data. This research approach using the approach of the case (case approach and qualitative approach. Regarding the data, the authors obtained data from interviews and literature study.

These results indicate (1) Factors increasing request for married dispensation in the Religious Court of Blora is (a) Fearing the emergence of slander, (b) pregnant outside of marriage (2) Judge Consideration of Religion Court of Blora in granted married dispensation, based on consideration of three things namely (a) Administrative completeness, (b) there is no prohibition of marriage as contained in Article 8 of Act No. 1 of 1974 On Marriage, (c) the principle benefit (3) weakness of marriage Act in the execution of court and solutions for reduce married dispensation in the Religious Court of Blora. Lack of socialization to the relevant institutions make weak law marriage in the implementation of the court.

Keywords: Judge Consideration; Religious Court; Married Dispensation.
\end{abstract}

\section{Introduction}

Marriage is the dream of everyone in the world. Together and happy life is hope in marriage. Science Figh marriage according to the terms used the word "marriage" and the words "Ziwaaj". According to the true meaning of marriage is "Dham" means squeezing, crushing or gathered while the meaning is "wathaa" meaning "Agreement" means holding the wedding. ${ }^{4}$

The government has issued the Marriage Act National has long aspired by the people of Indonesia, namely Act No. 1 of 1974 About the marriage, which was then for the smooth execution issued by a Government Regulation on the Implementation of Act No. 1 of 1974 On Marriage, namely the Indonesian Government Regulation No. 9 of 1975. Act No. 1 of $1974^{5}$ Act No. 16 Of $2019^{6}$ contains a very broad content, which is silent on the matter of marriage, divorce, child seat, rights and obligations between parents and children, san also set up a trust problem and set about proving the origin of the child.

One of the requirements under the Marriage Act is adhered on the lowest age limit to mate. It is stipulated in Article 7 paragraph 1, which reads: "Marriage is only permitted if the man and woman has reached the age of 19 (nineteen) years". And in Article 7, paragraph 2 explained "In this case the deviation of the provisions age as where referred

\footnotetext{
${ }^{1}$ Student of Master of Law, Universitas Islam Sultan Agung Semarang and PPNPN of Religious Court of Blora, Central Java Province, e-mail muzazanah.azzam@gmail.com

${ }^{2}$ Lecturer of Master of Law, Sultan Agung Islamic University (UNISSULA), Semarang

${ }^{3}$ Lecturer of Master of Law, Sultan Agung Islamic University (UNISSULA), Semarang

${ }^{4}$ Sayyid Sabiq, 2011, Fikih Sunnah 3, Cakrawala Publishing, Jakarta, p. 197.

${ }^{5}$ Law of the Republic of Indonesia Number 1 of 1974 On Marriage, 1974, Wipress, p. 459

${ }^{6}$ www.hukumonline.com/pustakadata, accessed on December 9, 2019
} 
to in paragraph (1), the parent party of men and / or parents of the woman can request an exemption to the Court by reason of urgency accompanied by supporting evidence sufficient. $^{7}$ In Article stipulates the principle that the prospective spouses must be prepared body and soul to be able to mate, in order to realize the goal of marriage is good without ending up with divorce, and got a good and healthy offspring.

In the case that the authority of the Religious Court, there are some things that are very closely related to children's rights, including the case of application for married dispensation. Request a married dispensation is a case filed by the Applicant case that the Court grant permission to the requested dispensation to be married, because there is a requirement that is not met by the bride and groom, the marriage age limit compliance. ${ }^{8}$ In 2018 there were 98 petition, in 2019 there were 180 petition, so that from 2018 until 2019 rises to $90 \%$.

Causing factors marital dispensation is pregnant outside of marriage, economic factors, factors of education, lack of understanding of the laws of marriage and fears of parents to their children. Underage marriage has negative impacts and create new problems. First, spouses were married under the age prone to divorce. Secondly, in terms of reproductive health prone to child and maternal mortality. Third, a poverty usually underage marriages are particularly vulnerable to poverty because economically they are not ready to work. Fourth, the exploitation of children for married eventually they have to work and care for children. ${ }^{9}$

Basic legal considerations dispensation married by a judge in Religious Court of Blora legally is Act No. 1 of 1974 jo Act No. 5 of 2019 on Marriage in Article 7 paragraph 1, which reads: "Marriage is only allowed if a man and a woman has reached the age of 19 (nineteen years ". And in Article 7, paragraph 2 explained "In this case the deviation of the provisions age as where referred to in paragraph (1), the parent party of men and / or parents of the woman can request an exemption to the Court by reason of urgency accompanied by supporting evidence sufficient. In theory Maslahah is set yet No explanation is detailed in Al-Quran and Al-Hadith for consideration kindness and resist damage in public life, and in spite of efforts to prevent Madharat.

Based on the background of the problem, it can be formulated research problems as follows: What factors led to increased request for married dispensation in the Religious Court of Blora?; How consideration in the The Judge of Religious Court of Blora granted a married dispensation?; What is the weakness of Marriage Act in court and in the implementation of solutions to reduce married dispensation in the Religious Court of Blora?

\section{Research methodology}

Method the approach used is normative, which deductively began an analysis of the clauses in the regulations related invitation. Given that the problems studied ranged in

\footnotetext{
${ }^{7}$ Ibid.

${ }^{8}$ Majalah Peradilan Agama, 2016, Perlindungan Hak-hak Anak di Peradilan Agama, General Directory of the Supreme Court, p. 38.

${ }^{9}$ Rahmat Maulidia 2011, Dinamika Hukum Perdata Islam Di Indonesia (KHI), Ponorogo: STAIN po Press, p. 80.
} 
legislation and its relation to its application in practice. ${ }^{10}$ Data were collected by using secondary data is data obtained through library research. The literature can be: legislation, scientific works to scholars of jurisprudence (the judge's decision), and other sources.

\section{Results And Discussion}

\subsection{Causing Factors Which Increased The Request of Married Dispensation In Religious Court of Blora}

From statement one of judge in Religious Court of Blora said that the causing factors the increasing request for married dispensation are two things:

- Fearing the emergence of slander Implementation of the married dispensation in the Religious Court of Blora caused worry onset of slander, parents feel their children are often gathered together so that it is feared there will be things that are not desirable. Most of the area Blora is rural, as is the case among rural if a child of the opposite sex and adult often together then they will be taken into slander neighbors so that parents feel worried if things happen that are not desirable then the parents marry off their children in order to avoid slander.

- Unwed pregnancy

Promiscuity and the influence of the electronic media that are more advanced and more sophisticated, so for anyone, including children can access a variety of things from the electronic media, from the things that are positive can help in terms of education up to the things that are negative influence or adversely affect the educational, psychological and people's lives, especially children. From this resulted in frequent occurrence of pregnancy prior to their marriage or in other words married by accident.

Pregnant outside of marriage is the factor that dominates the dispensation mate, because married dispensation used the bridge to cover the disgrace the family and also to prevent further damage if not married.

From the results of the data obtained by researchers. That every year there must be a request for married dispensation filed in the Religious Court of Blora that we can see from the number of applications for married dispensation who entered in the Religious Court of Blora, especially in 2018 there were 98 request for married dispensation and in 2019 a number of 180 cases, an increase of $90 \%$ after the presence of changes in the marriage Act, that Act No. 16 of 2019, concerning the minimum age of marriage is 19 years for men and women.

In Act No.48 of 2009 regarding judicial judge in determining that a request be in accordance with the legal values and sense of justice in society. It is mentioned in paragraph (1) which states: "The judge and the judge shall explore, and understand the legal values and sense of justice in the society".

Thus, in the trial process the judge will ask the reasons what the cause of request for married dispensation in Religious Court of Blora in 2019. From the data obtained by researchers in a study in the Religious Court of Blora, for the Married Dispensation filed in Blora No Religion two factors that cause the increase request for married dispensation in Religious Court of Blora in 2019 is due to pregnancy outside of marriage and worried

10 Ronny Hanitijo Soemitro, 1990, Metode Penelitian Hukum dan Jurimetri, Jakarta: Penerbit Ghalia Indonesia, p.97. 
about the emergence of slander.

\subsection{Religious Court Judge Blora consideration in the grant application dispensation Married}

The judge is the one predicate attached to someone who has a job with special specifications in the field of law and justice with issues of freedom and justice legally in the context of a case. ${ }^{11}$ In this case the judge considered to know the law (juris curia notive). Matter of finding the law is a matter for the judge. So the judge in considering his verdict required for completing the legal reasons that is not discovered by the parties. ${ }^{12}$

Judge's considerations will be contained in the decision, a good decision is a decision that understands three elements are balanced aspect, namely the rule of law, justice, benefit. ${ }^{13}$ One of The Judge of Religious Court of Blora said that in considering the case married dispensation in terms of the benefit, the judges use principle fiqhiyah:

"Rejecting the damage shall take precedence over interesting benefit"

در عالمفا سد مقد معل جلب المصالح According to This rule, if in a case or beneficiaries are visible Mafsadah and Maslahat, then Mafsadah it should be eliminated because it can spread everywhere and cause a greater Mafsadah. In case dispensation this wedding that included Mafsadah was a child has violated the provisions of the law regulating the minimum limit of the implementation of marriage, namely Article 17 paragraph (1) of Act No. 1 of 1974 jo Act No. 16, 2019 About the marriage, Article 8 of the Regulation of the Minister of Religion No. 11 of 2007 Regarding Registration of Marriages and Article 15 Compilation of Islamic Law. And Maslahat by issuing a request married dispensation, in order to avoid damage to my mother and when a mother has given birth.

If seen in the provisions of Article 7 (1) of Act No. 1 of 1974 jo Act No. 16 Of 2019 about marriage, only allowed stabbed to men and women aged 19 years in Article 8 of Regulation No. 11 Of 2007 on Registration Marriages explained that if a candidate has not yet reached 19 years old husband and a wife candidate has not reached 19 years, then get a dispensation.

While Article 15 (1) Compilation of Islamic law confirms that for the benefit of the family and household, marriage should only be done if the prospective husband minimum 19 years and prospective wives of at least 16 years old, but Article 7 (2) of Act No. 16 of 2019 about marriage arranged that the divergence of the provision of age referred to in paragraph (1), the men's parents and / or parents of the woman can request an exemption to the Court by reason of urgency accompanied by evidence of sufficient support.

Result of the petition is granted a married dispensation would cause the number of underage marriages. As a result of underage marriage itself raises some impact to people's lives, especially for the culprit. The negative impact of them, rising divorce, maternal mortality rate of infants and children, cancer of the uterus or cervix cancer because of sex freely. The positive impact of them, clarify the status of marriage, to clarify the fate of

\footnotetext{
${ }^{11}$ Ahmad Kamil, 2012, Filsafat Kebebasan Hakim, Jakarta: Prenadamedia Group, p. 169.

${ }^{12}$ Dewi Iriani, 2016, Pengetahuan Ilmu Hukum dan Pengenalan Tentang Hukum di Indonesia, Ponorogo: CV. Senyum Indonesia, p. 96.

${ }^{13}$ Mukti Arto, 2004, Praktek Perkara Perdata pada Pengadilan Agama, Fifth Edition, Yogyakarta: Pustaka Pelajar, p. 35
} 
children who need a father figure or a figure, a good recognition of the environment, preventing uncontrolled fornication.

If The request was not granted would worry about going Mudharat more great, as was the case Sirri marriage or marriage under the hand nasab will lead to chaos. In addition the judge in grant it also considers as illegal relationship of marriage, with consideration of women who are pregnant outside of marriage would be insulted and ostracized by the community. And this will have an impact on women and children's self to be born.

\subsection{The weakness of Marriage Act in court and Solution Implementation for reducing the dispensation request Mating in the Religious Court of Blora}

One judge in Religious Court of Blora said that the weakness of Marriage Act in court that this was due to lack of socialization with relevant agencies or to the public.

Not yet their dissemination to agencies make weak law marriage in the implementation of the trial, because if the applicant did not receive a letter of recommendation as described in Article 15 letter (d) PERMA No. 5 of 2019, the application for a married dispensation the applicant could result in the application is not granted because it can not provide sufficient evidence.

Invite OF No. 16 of 2019 has not been fully provide legal protection and legal certainty to the dispensation. Since not promote the interests of the child, so it tends to ignore the rights of the child. The impact with regulations such as this raises the number of Sirri marriage, marriage under the arms and underage marriage through a married dispensation.

One judge in Religious Court of Blora said that reduce the solution to married dispensation request can be made through its role as follows: "It needs socialization Act of marriage in society and an age difference for men and women in marriage"

Socialization Act this marriage can be done anywhere, such as a school, mosque committees, seminars and lectures, which aims to provide an explanation to the public about the dangers related to early marriage, as a result of free socialization. Differences between male mating with a female influence in the case of application for a married dispensation. Because after the change of Act No.16 of 2019 About Marriage, request married dispensation in the Religious Court of Blora increased by $90 \%$, because the majority of the population in Blora is rural, so that when his daughter was 18 years old unmarried stigmatized, because they are not behavior.

\section{Closing}

\subsection{Conclusion}

- Factors increasing litigation married dispensation in Religious Court of Blora is due to: Fearing the emergence of slander, Parents worry when their children (of different types) are grown and often together then they would be slanderous material from its neighbors, so that parents feel worried if things happen that are not desirable; Unwed pregnancy, Promiscuity and the influence of the electronic media that are more advanced and sophisticated so that anyone can access on the positive and negative things. Pregnant outside of marriage is the factor that dominates the dispensation mate, because married dispensation bridge used to cover the family disgrace. 
- The Judge of Religious Court of Blora granted the married dispensation under consideration three things: Administrative requirements; There is no prohibition of marriage as contained in Article 8 of Act No. 1 of 1974 On Marriage; The principle benefit and Mudharat.

- The weakness of the Act in the trial because of lack of socialization of agency related the petition can not meet the evidence is sufficient, if the application is granted will result in the number of Sirri marriage and marriage under the hand. Solutions to reduce application for a married dispensation, namely (1) The socialization law marriage with the community, (2) Before the age difference between men and women. Due to the similarities between the ages of men to women is also the cause of the increasing request for married dispensation in the Religious Court of Blora.

\subsection{Suggestions}

Based on the fact that has been described above, the suggestion to the author to convey is as follows: Parents should supervise and greater attention to the child and to provide religious education. Because parents have an important role to the development of children so as not to irregularities; To the judges in the dispensation granted to marry should consider the positive and negative impacts that will be caused, so that the determination of the judge actually contains three elements, namely the rule of law, fairness and benefits to society; Academics and judges to provide socialization Act of marriage to society, about the purpose of marriage and give advice to them that are concerned about the issue a married dispensation, the dangers of promiscuity and married too early.

\section{References}

[1] Ahmad Kamil, 2012, Filsafat Kebebasan Hakim, Jakarta: Prenadamedia Group

[2] Dewi Iriani, 2016, Pengetahuan IImu Hukum dan Pengenalan Tentang Hukum di Indonesia, Ponorogo: CV. Senyum Indonesia

[3] Religious Courts magazine, in 2016, Perlindungan Hak-hak Anak di Peradilan Agama, 9th Edition, Jakarta: General Directory of the Supreme Court

[4] Mukti Arto, 2004, Praktek Perkara Perdata pada Pengadilan Agama, Fifth Edition, Yogyakarta: Pustaka Pelajar

[5] Nuansa Aulia, 2012, Kompilasi Hukum Islam, revised edition 2012, Jakarta: Nuansa aulia

[6] Rahmat Maulidia 2011, Dinamika Hukum Perdata Islam Di Indonesia (KHI), Ponorogo: STAIN po Press, p. 80.

[7] Ronny Hanitijo Soemitro, 1990, Jakarta: Metode Penelitian Hukum dan Jurimetri, PenerbitGhalia Indonesia

[8] Sayyid Sabiq2011, Fiqh Sunnah 3, Horizon Publishing, Jakarta.

[9] Act No. 23 of 2002 on Child Protection

[10] Law of the Republic of Indonesia Number 1 of 1974 On Marriage, 1974

[11] www.hukumonline.com/pustakadata, Accessed on December 9, 2019 